\title{
PERANCANGAN ALAT PENGHITUNG BENIH IKAN BERBASIS SENSOR OPTIK
}

\author{
Widagdo Purbowaskito', R. Handoyo² \\ ${ }^{1}$ Fakultas Teknologi Industri, Universitas Atma Jaya Yogyakarta, Jl. Babarsari No. 43, \\ Yogyakarta 55281, Indonesia \\ 2Departemen Teknik Pertanian dan Biosistem, Fakultas Teknologi Pertanian, \\ Universitas Gadjah Mada, Jl. Flora No. 1, Bulaksumur, Yogyakarta 55281, Indonesia \\ (0274) 487711 \\ E-mail: widagdo_purbowaskito@staff.uajy.ac.id
}

\begin{abstract}
Freshwater fish is one of important commodities for the people of Indonesia. High level of freshwater fish consumption in Indonesia leads to an enormous amount of freshwater fish embankment business. These freshwater fish embankment business are supported by fries cultivation business. One of the activities on the fries cultivation business is trading activity where the traded fries counting process is important. One of the problems on the counting process is that the counting process is done manually which is tend to be done inaccurately and time consuming. A proposed solution to alleviate this problem is the development of fries counter device by using optical sensor technology. The counter device consists of mechanical and electronics systems. The device is designed as a plastic box with three distribution pipes where on each pipe there is a transparent part installed with the optical sensor. Based on the testing results the optical sensor can be utilized as the counter sensor with accuracy result $91.4 \%$.
\end{abstract}

Keywords: fries, fry counter, design, optical sensor.

\section{PENDAHULUAN}

Ikan dan hewan perairan lainnya merupakan salah satu sumber protein bagi tubuh manusia terutama berfungsi sebagai unit pembangun dalam biosintesa bagian tubuh manusia yang rusak; serta pengatur dan pengontrol metabolisme tubuh [1]. Tingginya konsumsi ikan di Indonesia menjadikan usaha budidaya perikanan menjadi salah satu usaha yang cukup menjanjikan. Usaha budidaya perikanan sendiri sangat tergantung kepada usaha pembenihan ikan sebagai hulu dari usaha budidaya perikanan. Usaha budidaya pembenihan ikan memiliki posisi yang sangat penting. Namun dalam keberhasilan pelaksanaan usaha pembenihan ikan, bukan hanya ditentukan oleh kemampuan daya dukung lingkungan saja, tetapi oleh kemampuan dan mental pengelola [2].

Penghitungan benih dapat dilakukan dengan cara, yaitu manual dan volumetrik. Penghitungan cara manual adalah benih dihitung satu persatu sampai habis. Kelebihan cara ini yaitu jumlah benih yang dihitung sangat tepat. Namun, cara ini memerlukan waktu dan tenaga yang lama. Sementara Penghitungan secara volumetrik adalah benih dihitung dengan cara ditakar. Penakaran jumlah ikan ini berdasarkan pada volume wadah yang digunakan untuk menyimpan ikan. Pada volume tertentu diasumsikan terdapat sejumlah benih ikan, Cara ini dapat menghemat tenaga dan waktu [3]. Selain kedua cara tersebut penghitungan bibit ikan dapat dilakukan menggunakan metode estimasi berat seekor maupun beberapa ekor benih ikan. Metode ini dilakukan tanpa menggunakan air, sehingga hanya benih ikan saja yang ditimbang. Estimasi jumlah benih ikan menggunakan metode ini berdasarkan dari berat beberapa ekor benih ikan yang ditimbang [4].

Metode penghitungan manual memiliki beberapa kekurangan seperti subyektifitas penghitungan, waktu yang dibutuhkan lama, kelelahan orang yang menghitung, dan ketidak akuratan hasil penghitungannya [5]. Metode penghitungan otomatis diharapkan memberikan solusi terhadap kekurangan yang diperoleh dari metode penghitungan manual. Metode penghitungan otomatis sendiri telah diterapkan pada beberapa aplikasi. Aplikasi penghitung otomatis telah diterapkan untuk keperluan penghitungan jumlah orang baik yang dalam proses keluar-masuk ruangan 
maupun yang berada didalam ruangan. Piranti sensor yang digunakan dalam kegiatan penghitungan jumlah orang ini bermacammacam diantaranya, sensor light dependent resistor (LDR), infrared, dan ultrasonic [6] [7]. Selain itu metode penghitungan otomatis juga diterapkan pada aplikasi dalam bidang transportasi seperti pada proses penghitungan jumlah kendaraan. Metode penghitungan ini diterapkan baik pada kegiatan pemarkiran maupun pemantauan jumlah kendaraan yang berada di jalan raya. Piranti sensor yang digunakan pada proses penghitungan jumlah kendaraan diantaranya, sensor infrared, fototransistor, laser, dan ultrasonic [8] [9] [10]. Pada bidang industri penerapan metode penghitungan otomatis diterapkan pada proses penghitungan jumlah barang. Proses penghitungan jumlah barang otomatis ini memanfaatkan penggunaan sensor light dependent resistor (LDR), infrared, dan fotodioda [11] [12].

Pada metode penghitungan otomatis yang telah diterapkan pada beberapa aplikasi, secara umum sensor optik yang lebih banyak digunakan dibandingkan sensor suara. Aplikasi sensor optik sendiri tidak hanya terbatas pada aplikasi penghitungan otomatis namun juga dapat diaplikasikan pada bidang lain seperti, penentuan jarak dan penempatan pupuk urea bola untuk pemupukan padi, pengukuran panjang dan berat, pendeteksi gerak manusia, pendeteksi garis, dan navigasi untuk mobile robot [13] [14] [15] [16] [17]. Diharapkan pada penelitian ini sensor optik dapat juga diterapakan sebagai metode penghitungan jumlah benih ikan otomatis.

Metode penghitungan otomatis sendiri telah diterapkan untuk proses penghitungan jumlah benih ikan. Metode penghitungan benih ikan ini dilakukan dengan memanfaatkan teknologi pengolahan citra digital (digital image processing). Teknologi ini menggunakan metode pengolahan baik foto maupun video untuk melakukan proses penghitungan jumlah benih ikan [4] [18] [19]. Penghitungan benih ikan menggunakan teknologi pengolahan citra membuktikan bahwa metode penghitungan benih ikan otomatis dapat dilakukan. Namun penerapan teknologi pengolahan citra sangatlah belumlah tepat guna, pengoperasiannya rumit, dan memerlukan biaya yang cukup besar.
Sehingga pada penelitian ini akan dirancang suatu teknologi tepat guna untuk proses penghitungan benih ikan menggunakan penerapan teknologi sensor optik sebagai sensor penghitung benih ikan. Rancangan yang dibuat diharapkan dapat digunakan dengan mudah oleh pengguna untuk menghitung jumlah benih ikan.

\section{METODOLOGI PENELITIAN \\ Waktu dan tempat}

Penelitian ini dilaksanakan pada bulam Maret 2013 sampai dengan bulan September 2013 bertempat di Laboratorium Energi dan Mesin Pertanian, Departemen Teknik Pertanian dan Biosistem, Fakultas Teknologi Pertanian, Universitas Gadjah Mada, Yogyakarta.

\section{Instrumen penelitian}

Pada penelitian ini digunakan beberapa bahan untuk mendukung proses perancangan dan manufaktur alat penghitung benih ikan otomatis seperti software, komponen elektronika, komponen mekanis, serta peralatan perbengkelan. Beberapa software yang digunakan meliputi software Bascom AVR 1.11, universal ISP programmer 1.03, dan program Eagle 5.3. Komponen elektronika yang digunakan meliputi 2 buah IC mikrokontroler ATMega8, 3 buah LED $5 \mathrm{~mm}, 3$ buah sensor fototransistor, 2 buah probe elektroda, 1 buah IC OPAMP LM324, dan 1 display LCD. Beberapa komponen mekanis yang digunakan meliputi 1 buah box plastik, 3 buah pipa penyalur yang sudah dimodifikasi, dan besi siku sebagai bahan rangka.

\section{Kriteria perancangan}

Konsep dasar pada perancangan alat penghitung benih ikan ini mempertimbangkan pada beberapa hal berikut ini,

1. Perancangan pipa saluran pengeluaran benih ikan dirancang dengan sudut kemiringan $45^{\circ}$. Hal ini dilakukan untuk mencegah benih ikan berenang melawan arus dan memperkecil peluang benih ikan tidak melewati sensor.

2. Perancangan ini juga dilengkapi dengan sensor pendeteksi permukaan air. Sensor ini ditambahkan karena pada lubang outlet yg terdapat pada box akan terjadi pusaran sesaat sebelum air dalam box habis. Pusaran ini memungkinkan munculnya gelembung udara dan riak air yang menyebabkan sensor penghitung 
menghitungnya. Sensor ini berfungsi untuk mencegah hal tersebut dengan menghentikan fungsi sensor penghitung sesaat sebelum air habis.

3. Perancangan panel kontrol alat dilakukan secara sederhana terdiri dari tombol ON/OFF, tombol RESET, dan display LCD. Panel kontrol sederhana ini dirancang agar pengguna dapat dengan mudah menggunakannya.

\section{Perancangan mekanik}

Rancangan mekanik alat penghitung benih ikan otomatis terdiri dari rangka alat yang terbuat dari besi siku berukuran $40 \times 40 \times 4 \mathrm{~mm}$, bak penampung yang terbuat dari plastik dengan tiga lubang oultet yang pada masingmasing lubang terdapat pipa yang digunakan untuk menyalurkan benih ikan dari bak penampung plastik. Pada pipa tersebut terdapat bagian transparan dimana sensor penghitung benih ikan akan diletakkan. Pada bagian ujung ketiga pipa diletakkan penutup yang dilengkapi dengan engsel dan dikaitkan pada dua buah pegas agar penutup tersebut mudah dibuka dan ditutup. Penutup tersebut dilapisi dengan material karet pada bagian yang terkontak dengan lubang pipa agar tidak terjadi air yang menetes pada saat bak penampung diisi air dan benih ikan. Keseluruhan rancangan alat berukuran 520x440x740mm. Gambar dan informasi mengenai rancangan mekanik alat penghitung benih ikan dapat dilihat pada Gambar 1.

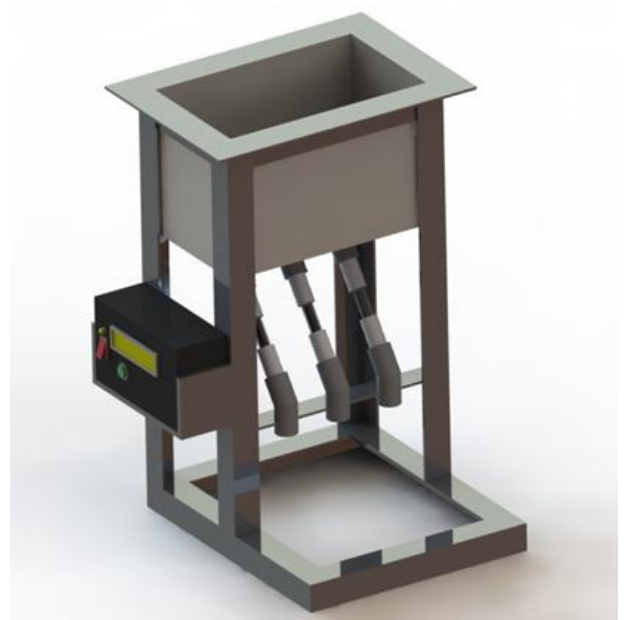

Gambar 1. CAD perancangan alat penghitung benih ikan otomatis

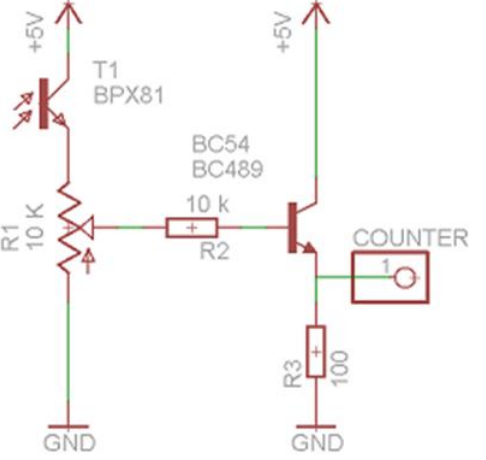

Gambar 2. Skematik rangkaian sensor fototransistor

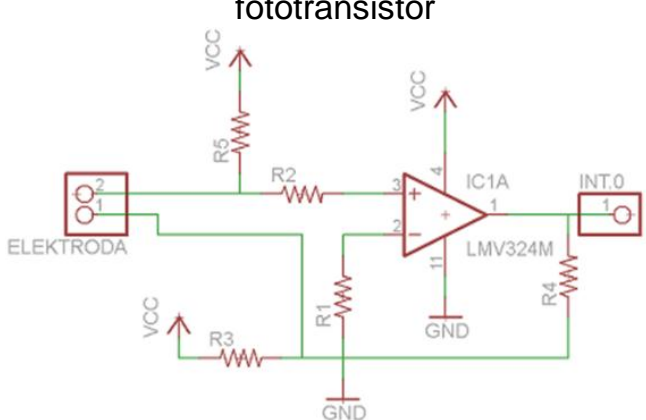

Gambar 3. Skematik rangkaian sensor pendeteksi permukaan air

\section{Perancangan elektronika}

Sensor penghitung benih ikan dirancang dengan metode transceiver dengan menggunakan LED $5 \mathrm{~mm}$ sebagai transmitter dan sensor optik fototransistor $5 \mathrm{~mm}$ sebagai receiver. Sensor fototransistor ini terkoneksi pada port counter yang ada pada mikrokontroler. Rangkaian sensor fototransistor dapat dilihat pada gambar 2. Sensor penghitung bekerja dengan transmitter yaitu LED memancarkan sinyal/gelombang berupa cahaya dan diterima oleh fototransistor sebagai receiver. Prinsip kerja fototransistor adalah bila terdapat sinar yang diterima fototransistor akan membangkitkan arus basis (lb) dan diubah menjadi tegangan $(\mathrm{V})$ oleh variable resistor dan diterima oleh counter dalam bentuk tegangan. Pada saat fototransistor menangkap cahaya maka input yang diterimanya dari sumber cahaya adalah dalam bentuk tegangan. Dan apabila fototransistor tidak menerima cahaya berarti tidak ada input berupa tegangan. Berdasarkan prinsip inilah proses penghitungan ikan dilakukan. Benih ikan dapat terhitung apabila tidak ada cahaya yang diterima fototransistor. 


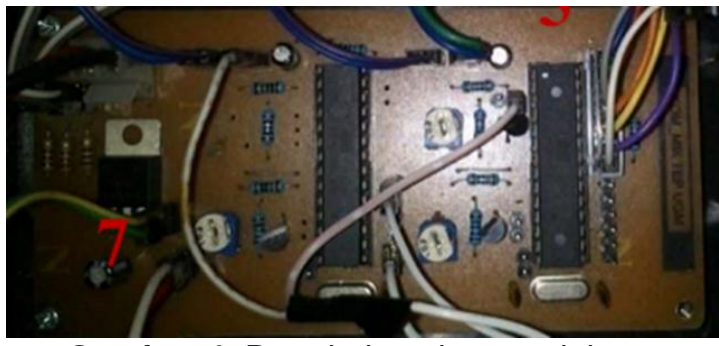

Gambar 4. Rangkaian sistem minimum dengan dua mikrokontroler

Sesuai dengan kriteria perancangan no. 2, pada alat penghitung benih ikan ini akan dilengkapi dengan sensor pendeteksi permukaan air. Rangkaian sensor permukaan air dapat dilihat pada gambar 3. Sensor ini dirancang menggunakan 2 buah probe elektroda tembaga yaitu, probe 1 dan probe 2 yang terhubung pada rangkaian IC OPAMP LM324. Rangkaian IC ini merupakan rangkaian komparator yang berfungsi membandingan antara probe elektroda 1 dengan probe elektroda 2. Melalui program yang ditanam pada mikrokontroler pada probe elektroda 1 diberikan logika 0 . Sedangkan pada probe elektroda 2 diberikan logika yang dapat berubah-ubah tergantung kondisi probe diletakkan, saat berada didalam air probe 2 berlogika 0 dan saat diluar air probe 2 berlogika 1. Sehingga saat berada dalam air probe 1 dengan probe 2 akan terhubung dengan kedua logikanya 0 dan mengakibatkan sensor penghitung aktif. Namun saat kedua probe tidak berada didalam air maka probe 1 berlogika 0 dan probe 2 berlogika 1 dan mengakibatkan sensor penghitung tidak aktif.

Alat penghitung benih ikan ini menggunakan dua buah mikrokontroler dengan jenis AVR seri ATMega8. Sistem minimum dua mikrokontroler ini dapat dilihat pada gambar 4. Kedua mikrokontroler ini berkomunikasi menggunakan metode komunikasi serial. Mikrokontroler ATMega8 hanya memiliki 2 buah port counter sedangkan alat penghitung benih ikan ini dirancang dengan 3 buah sensor penghitung. Sehingga perlu ditambah 1 buah mikrokontroler tambahan sehingga 3 buah sensor penghitung dapat direalisasikan. Selain sebagai pusat operasi penghitungan mikrokontroler ini digunakan juga untuk menerima input dari sensor air dan memberikan output pada display LCD.

\section{HASIL DAN PEMBAHASAN Hasil perancangan}

Alat penghitung benih ikan ini dilengkapi dengan bak penampung dengan kapasitas tampungan air 6 liter untuk menampung benih ikan sebelum dihitung yang dilengkapi sensor permukaan air dan 3 buah pipa untuk mengalirkan benih yang pada masing-masing pipanya dilengkapi dengan sensor fototransistor. Untuk mengendalikan dan mengolah data yang diterima sensor pada alat penghitung benih ikan ini digunakan 2 buah IC mikrokontroler Atmel ATMega8 yang saling berhubungan menggunakan komunikasi serial USART (The Universal Synchronous and Asynchronous serial Receiver and Transmitter).

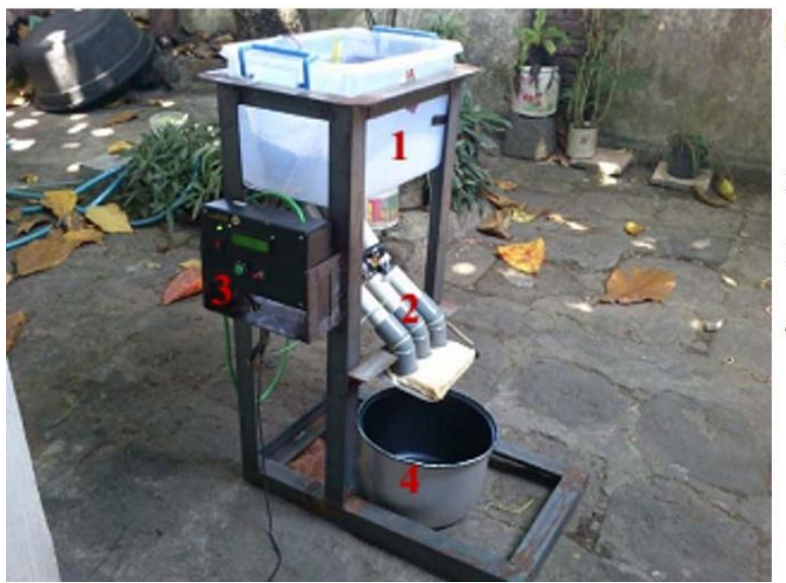

Keterangan:

1. Bak Penampung Plastik

2. Pipa Penyalur

3. Kotak Panel

4. Wadah Benih Ikan

Gambar 5. Hasil perancangan alat penghitung benih ikan 


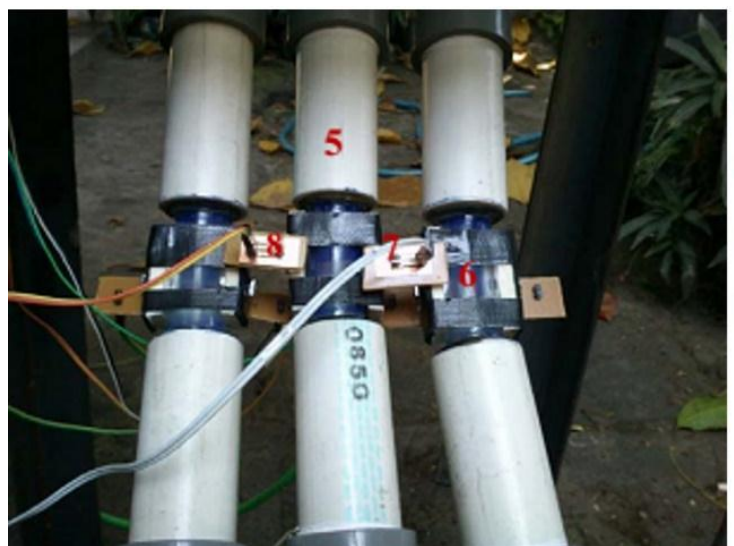

Keterangan:

5. Pipa PVC

6. Pipa Transparan

7. Sensor Fototransistor

8. Sumber Cahaya (LED)

Gambar 6. Bagian-bagian pada pipa penyalur

Sensor fototransistor dan LED dipasang pada bagian transparan pipa sehingga cahaya yang dihasilkan LED dapat menembus dan menyinari fototransistor. Pada saat tidak ada ikan yang melewati pipa maka fototransistor menerima tegangan input dari cahaya LED sedangkan saat ada ikan melewati pipa dan menutupi cahaya LED maka tidak ada tegangan input yang diterima fototransistor. Rangkaian sensor fototransistor ini dihubungkan pada mikrokontroler ATMega8 melalui pin PD2 atau PD3 yang berfungsi sebagai timer/counter. Melalui program yang ditulis dan dimasukkan kedalam mikrokontroler kedua pin tersebut diaktifkan sebagai counter dan bekerja berintegrasi dengan rangkaian sensor fototransistor.

\section{Hasil kaliberasi sensor penghitung}

Kalibrasi pada sensor perlu dilakukan pada tahap awal sebelum penggunaan alat agar dapat diketahui apakah sensor yang terdapat pada alat berfungsi dengan baik. Kaliberasi pada sensor fototransistor yang terdapat pada masing-masing pipa dilakukan dengan metode buka tutup cahaya yang berasal dari LED (Light Emitting Diode) ke sensor fototransistor. Validasi hasil kalibrasi dilakukan dengan membandingkan jumlah buka tutup cahaya dengan bacaan hasil pada display LCD. Berdasarkan data pada tabel 1. diperoleh informasi bahwa keakuratan sensor dalam menerima rangsang cahaya mencapai $100 \%$. Hal ini menunjukkan bahwa tidak ada masalah dalam kinerja rangkaian elektronik sensor fototransistor pada alat penghitung benih ikan.

Tabel 1. Tabel hasil kalibrasi sensor penghitung melalui perlakuan buka tutup cahaya

\begin{tabular}{cccccccc}
\hline \multirow{2}{*}{ No } & \multicolumn{3}{c}{ Banyak Buka Tutup Cahaya } & \multicolumn{4}{c}{ Hasil Pengukuran Buka Tutup } \\
\cline { 2 - 8 } & Sensor A & Sensor B & Sensor C & A & B & C & Jumlah $^{*}$ \\
\hline 1 & 50 & 50 & 50 & 50 & 50 & 50 & 150 \\
2 & 100 & 100 & 100 & 100 & 100 & 100 & 300 \\
3 & 150 & 150 & 150 & 150 & 150 & 150 & 450 \\
4 & 200 & 200 & 200 & 200 & 200 & 200 & 600 \\
5 & 250 & 250 & 250 & 250 & 250 & 250 & 750 \\
6 & 300 & 300 & 300 & 300 & 300 & 300 & 900 \\
7 & 350 & 350 & 350 & 350 & 350 & 350 & 1050 \\
8 & 400 & 400 & 400 & 400 & 400 & 400 & 1200 \\
\hline
\end{tabular}

*Jumlah $=\mathrm{A}+\mathrm{B}+\mathrm{C}$ 
Tabel 2. Data hasil pengujian alat penghitung benih ikan

\begin{tabular}{|c|c|c|c|c|c|c|}
\hline \multirow{2}{*}{$\begin{array}{l}\text { Jumlah } \\
\text { Acuan }\end{array}$} & \multicolumn{4}{|c|}{ Bacaan Hasil Penghitungan } & \multirow{2}{*}{$\begin{array}{l}\text { Kesalahan } \\
\text { Hitung }\end{array}$} & \multirow{2}{*}{ Akurasi } \\
\hline & A & $B$ & $\mathrm{C}$ & $\mathrm{Jl}$ & & \\
\hline 40 & 22 & 7 & 5 & 34 & 6 & 0.85 \\
\hline 40 & 14 & 15 & 6 & 35 & 5 & 0.88 \\
\hline 40 & 28 & 9 & 2 & 39 & 2 & 0.98 \\
\hline 50 & 21 & 21 & 7 & 49 & 1 & 0.98 \\
\hline 50 & 20 & 15 & 3 & 44 & 6 & 0.88 \\
\hline 50 & 14 & 18 & 12 & 44 & 6 & 0.88 \\
\hline 60 & 22 & 18 & 12 & 52 & 8 & 0.87 \\
\hline 60 & 20 & 16 & 20 & 56 & 4 & 0.93 \\
\hline 60 & 17 & 13 & 29 & 59 & 1 & 0.98 \\
\hline \multicolumn{6}{|c|}{ Rerata Akurasi } & 0.914 \\
\hline & & $\begin{array}{l}=\text { rera } \\
=0.91 \\
=91.4\end{array}$ & & & & \\
\hline
\end{tabular}

\section{Hasil pengujian alat}

Pengujian alat penghitung benih ikan dilakukan dengan menggunakan tiga jenis jumlah acuan yaitu benih ikan sebanyak 40,50 , dan 60 dengan masing-masing jumlah dilakukan pengulangan penghitungan sebanyak tiga kali. Pertama-tama benih ikan dengan jumlah tersebut dimasukkan kedalam bak penampung lalu setelah itu penutup pada pipa dibuka dan air beserta benihnya dikeluarkan melalui pipa penyalur dengan prinsip kerja seperti pada gambar 7. Pada gambar 7, benih ikan akan mengalir melalui ketiga pipa penyalur dan benih ikan akan melalui bangian pipa transparan yang terdapat sepasang transciever sensor optik. Hasil penghitungan tiap sensor dan totalnya dapat diamati melalu layar display LCD. Data hasil pengujian alat ini tersaji pada tabel 2.

Pada tabel 2. dapat diamati bahwa hasil penghitungan otomatis benih ikan dengan menggunakan sensor optik fototransistor mungkin untuk dilakukan. Sensor yang dirancang telah terbukti dapat dimanfaatkan untuk proses penghitungan benih ikan. Hasil pengamatan penggunaan benih ikan ini juga menunjukkan bahwa masih terdapat kesalahan hitung yang dilakukan oleh sensor penghitung benih ikan.

Kelemahan sensor penghitung yang dirancang adalah yaitu dikarenakan sensor bekerja karena hanya dapat membaca respon ada dan tidaknya cahaya yang diterima sensor optik fototransistor. Sehingga untuk posisi dua atau lebih benih ikan yang overlapping seperti yang disajikan pada gambar 8 dan gambar 9 terbaca oleh sensor hanya berjumlah satu ekor beinh ikan. Kendati pada penelitian ini sensor yang dirancang masih terdapat kesalahan dalam penghitungannya, secara keseluruhan hasil penghitungan yang dilakukan oleh alat penghitung memiliki keakuratan yang cuku yaitu $91.4 \%$ dimana kesalahan yang terdapat masih dibawah $10 \%$ yaitu $8.6 \%$.

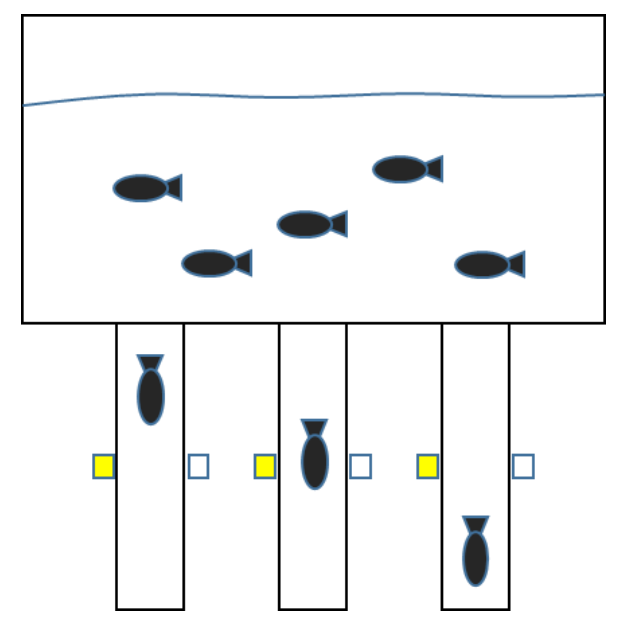

Gambar 7. Proses penghitungan benih ikan pada alat penghitung 
1

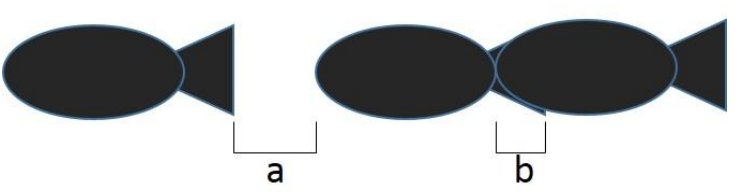

Gambar 8. Overlapping posisi horizontal benih ikan

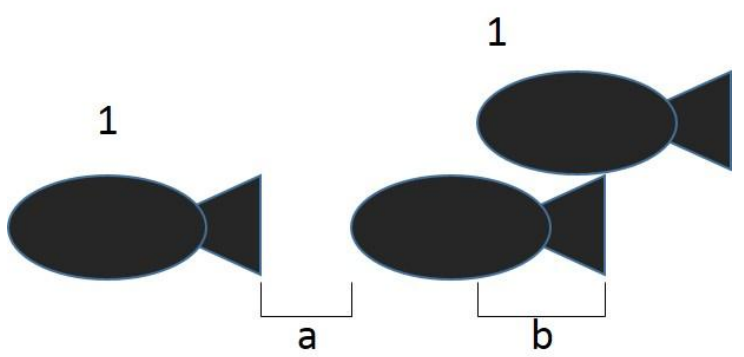

Gambar 9. Overlapping posisi vertical benih ikan

Berdasarkan hasil yang diperoleh pada tabel 2, dapat diamati bahwa perilaku benih ikan cenderung untuk berenang berkerumun kearah pojok bak penampung. Hal ini dapat diamati ketika jumlah acuan benih ikan bertambah persebarannya di dalam bak penampung mulai merata. Berdasarkan data yang tersaji densitas benih ikan pada bak penampung apabila bagi menjadi 3 bagian berdasarkan jumlah lubang yaitu 15-25 benih/bagian.

\section{KESIMPULAN}

Berdasarkan hasil perancangan dan pengujian alat penghitung benih ikan dilakukan maka diperoleh kesimpulan sebagai berikut:

1. Pemanfaatan teknologi sensor optik untuk penghitungan benih ikan dapat dilakukan dan bekerja dengan baik.

2. Hasil akurasi penghitungan alat sebesar $91.4 \%$ dengan kesalahan $8.6 \%$.

3. Kesalahan utama penghitungan disebabkan kemampuan sensor yang hanya dapat membedakan antara ada dan tidak adanya cahaya. Sehingga pada kondisi overlapping jumlah benih ikan yang lebih dari satu, sensor hanya menghitung sejumlah satu benih.

\section{UCAPAN TERIMA KASIH}

Ucapan terima kasih terutama ditujukan kepada DIKTI melalui pendanaan pada Program Krativitas Mahasiswa bidang Penerapan Teknologi tahun 2013. Ucapan terima kasih dapat juga disampaikan kepada Dualim Atma Dewangga dan Bapak Marheri yang telah membantu proses pengerjaan perbengkelan alat penghitung benih ikan ini. Lalu ucapan terimakasih kepada bapak Sumitra selaku mitra pada proses penelitian ini. Serta ucapan terimakasih kepada tim PKM-T Fishop atas kerjasamanya selama proses pelaksanaan PKM ini.

\section{DAFTAR PUSTAKA}

[1] Suwetja. 2011. Biokimia Hasil Perikanan. Jakarta: Media Prima

[2] Murtidjo, B A. 2001. Beberapa Metode Pembenihan Ikan Air Tawar. Yogyakarta: Kanisius

[3] Sasongko, A. 2007. Sidat: Panduan Agribisnis Penangkapan, Pendederan, dan Pembesaran. Depok: Penebar Swadaya

[4] Adhi, M. Z. K. 2011. Pengembangan Metode Penghitungan Benih Ikan Lele dengan Pengolahan Citra dan Metode Penimbangan Benih. Fakultas Teknologi Pertanian. Institut Pertanian Bogor, Indonesia

[5] Seminar, K. B. 2000. Desain Alat Penghitung Bibit Ikan dengan Multisensor Paralel. Buletin Keteknikan Pertanian 14(2): 128-133

[6] Miftahudin, A. 2007. Simulator Penghitung Jumlah Orang pada Pintu Masuk dan Keluar Gedung. Fakultas Teknik. Universitas Negeri Semarang. Semarang, Indonesia

[7] Raka Agung, I. G. A. P., Susanto, I. M. I. 2012. Rancangbangun Prototipe Penghitung Jumlah Orang dalam Ruangan Terpadu berbasis Mikrokontroler ATMega328P. Jurnal Teknologi Elektro 11(1): 41-49

[8] Ary, R. S., Manan, S. 2013. Simulasi Sistem Penghitung Jumlah Mobil Keluar dan Penghitungan Tarifnya berdasarkan Lama Waktu pada Gedung Parkir Mobil Berlantai Tiga berbasis Mikrokontroler 
Atmega 8535. Gema Teknologi 17(3): 108115

[9] Zulkurniawan, Suprapto, B. Y., Dinata, I. 2015. Rancang Bangun Penghitung Jumlah Kendaraan Roda Empat Secara Otomatis berbasis Mikrokontroler AT89S51. Jurnal Ecotipe 2(1): 26-33

[10] Hardiyanto, R. D., Rochim, A. F., Windasar, I. P. 2015. Pembuatan Penghitung Jumlah Mobil Otomatis Berbasis Mikrokontroler ATMega 8535 menggunakan Sensor Ultrasonik. Jurnal Teknologi dan Sistem Komputer 3(2): 185191

[11] Nurdiansah, I. 2010. Rancang Bangun Alat Penghitung Jumlah Barang dengan menggunakan Sensor LDR berbasis Mikrokontroler. Fakultas Matematika dan IImu Pengetahuan Alam. Universitas Sebelas Maret, Surakarta, Indonesia

[12] Yohannes, C. 2011. Sistem Penghitung Jumlah Barang Otomatis dengan Sensor Ultrasonik. Elektrikal Enjiniring 9(2): 66-71

[13] Handoyo R., Momong, L. W., Widodo. 2001. Control of Sinking Distance of Ball Urea Fertilizer with Light Sensor. Proceeding 2nd IFAC-CIGR Workshop On Intellinget Control For Agricultural Application. Ed. Hadi K. Purwadaria et al. Bali, Indonesia 22-24 August 2001

[14] Fajri, N., Wildian. 2014. Rancang Bangun Alat Ukur Tinggi dan Berat Badan Bayi berbasis Mikrokontroler ATMega8535 bengan Sensor Fototransistor. Jurnal Fisika Unand 3(3): 163-169

[15] Priyono, D. T., Sukadi. 2012. Perancangan Sistem Deteksi Gerak dengan Sinar Laser menggunakan Mikrokontroler Atmega 8 pada Laboratorium Komputer Sekolah Tinggi Keguruan dan IImu Pendidikan PGRI Pacitan. Indonesian Jurnal on Computer Science Speed 9(3): 62-69

[16] Hooi Ng, K., Yeong, C. F., Ming Su, E. L., Lim, T. Y., Subramaniam, Y., Teng, R. S. 2012. Adaptive Phototransistor Sensor for Line Finding. Procedia Engineering 41: 237 - 243. International Symposium on Robotics and Intelligent Sensors 2012.

[17] Chiu, Y-C., Yang, P-Y., Grift, T. E. 2014. A Wireless Communication System for Automated Greenhouse Operations. Biosystems Engineering 7(2): 78-85

[18] Seniatussa'adah. 2008. Otomatisasi Size Grading Benih Ikan. Fakultas Perikanan dan IImu Kelautan. Institut Pertanian Bogor, Indonesia

[19] Sinukun, R. S., Hardi, S., Purnomo, M. H. 2014. Identifikasi Jumlah Citra Nener menggunakan Metode Blob. Prosiding Seminar Nasional Aplikasi Sains \& Teknologi (SNAST) Yogyakarta 2014: 99104 